\title{
SOCIAL EXCLUSION AND CHALLENGES FACED BY TRANSGENDER COMMUNITY(A SOCIOLOGICAL APPROACH TO THE STUDY OF TRANSGENDER COMMUNITY IN TAMIL NADU)
}

\author{
J. Vanitha \\ Faculty of Sociology, Loyola College (Autonomous), Chennai, India \\ E-mail:vanithaedwin@gmail.com/vanithaj@loyolacollege.edu
}

\begin{abstract}
Indian society is been stratified based on religion, caste, education, class, language and it interconnects with gender too. Social exclusion based on these stratifications occurs in the society largely. Mostly, Indians accept, respect and tolerate a wide range of differences in cultures, religions, languages, and customs. Despite Indian society's general ambiance of acceptance and tolerance, there appears to be limited public knowledge and understanding of same-sex sexual orientation and people whose gender identity and expression are dissimilar with their biological sex. Majority of the people think of gender as a kind of inalienable property of individuals, as something we either are or have. Hence, when gender non-conformity is evident in a person, exclusion of that person is being practiced even in their family of orientation. Although transgender community has recognition in Hindu society to some extent, in contemporary context, their gender non-conformity makes them socially excluded. Therefore, this article will analyze and discuss on social exclusion of transgender community with special reference to Tamil Nadu. This article aims to:
\end{abstract}

Highlight the extent of social exclusion and corresponding problems faced by transgender community of Tamil Nadu.

Address the challenges faced by the transgender community of Tamil Nadu.

Identify the solutions to the problems and challenges faced by the transgender community.

The article explores contemporary research studies on transgender community, for instance, while transsexual studies was focused mostly on male-to-female transsexual perspective, this article also includes female-to-male transsexual and transgender community. This article is complied with case studies as primary sources and the secondary data available in the field of sociology along with some of the inputs from other disciplines such as history, economics and psychology. This article also reveals current trends of sociological inquiry in the area of transgender community in Tamil Nadu as a discussion of sociology's possible contributions towards transgender community.

Keywords: transgender community, social exclusion, problems, challenges, solutions

\section{Introduction}

Indian society is been stratified based on religion, caste, education, class, language and it interconnects with gender too. Social exclusion based on these stratifications occurs in the society largely. Mostly, Indians accept, respect and tolerate a wide range of differences in cultures, religions, languages, and customs. Despite Indian society's general ambiance of acceptance and tolerance, there appears to be limited public knowledge and understanding of same-sex sexual orientation and people whose gender identity and expression are dissimilar with their biological sex. Majority of the people think of gender as a kind of inalienable property of individuals, as something we either are or have. Hence, when gender non-conformity is evident in a person, exclusion of that person is being practiced even in their family of orientation. Although transgender community has recognition 
in Hindu society to some extent, in contemporary context, their gender non-conformity makes them socially excluded. Therefore, this article will analyze and discuss on social exclusion of transgender community with special reference to Tamil Nadu. This article aims to:

- Highlight the extent of social exclusion and corresponding problems faced by transgender community of Tamil Nadu.

- Address the challenges faced by the transgender community of Tamil Nadu.

- Identify the solutions to the problems and challenges faced by the transgender community.

The article explores contemporary research studies on transgender community, for instance, while transsexual studies was focused mostly on male-to-female transsexual perspective, this article also includes female-to-male transsexual and transgender community. This article also focuses on sociological analyses incorporating critical theory, queer theory, ethno methodology, labeling, feminist, and symbolic interactionist framework research studies. This article is complied with case studies as primary sources and the secondary data available in the field of sociology along with some of the inputs from other disciplines such as history, economics and psychology. This article also reveals current trends of sociological inquiry in the area of transgender community in Tamil Nadu as a discussion of sociology's possible contributions towards transgender community.

\section{Defining Transgender community:}

The term 'transgender community' is generally, used to describe those who transgress social gender norms. Transgender community is often used as an umbrella term to signify individuals who defy rigid, binary gender constructions, and who express or present a breaking and/or blurring of culturally prevalent stereotypical gender roles. Transgender community are referred as 'Thirunar', 'Thirunangai' for transfeminine people and 'Thirunambi' for transmasculine people. The term 'Aravaani' in Tamil was widely used before 1990's, which was also a substitute term of Hijra in India. 'Sangam Literature' use the word 'Pedi' to refer to people born with this condition. Until recently, HIV programs in India included transgender community women under the epidemiological and behavioural term - 'men who have sex with men' (MSM), although many transgender community people did not want to be included under that term. Tamil Nadu has an estimated population of more than 30,000 transgender community people (Chakrapani, 2014). Tamil Nadu Government has made great strides in trying to integrate transgender community people into society. This includes establishment of Tamil Nadu Transgender Community Welfare Board (TGWB), welfare schemes initiated by the Government, admitting transgender community in schools and colleges and acceptance of transgender community people into the mainstream media and film industry (Chakrapani, 2012). Even though this is one scenario, equally one can find transgender community facing social exclusion among the society they live.

\section{Social Exclusion of Transgender community:}

Human rights violations against sexual minorities including the transgender community in India have been widely documented. Social exclusion does not refer to the deliberate exclusion of transgender community, but also exclusion of transgender community unknowingly by portraying them faultily or labeling them incessantly. Social exclusion framework is been seen, as having particular salience in addressing the barriers to meeting the Millennium Development Goals (MDG's), particularly where these relate to exclusionary social relations and institutions (Robert, 2009).Adapting the Social Exclusion Framework to transgender community, one can understand how transgender community are been excluded from efficiently participating in social life, cultural life, education and economic systems. This section highlights the multiple forms of oppression faced by transgender community especially in Tamil Nadu and in world at large. 


\section{A. Exclusion from Social and Cultural Life:}

Transgender community faces exclusion because of high level of stigma and discrimination in almost every walk of their life. Exclusion of transgender community starts right from their family and extends to neighbourhood and society.

\section{Exclusion from family and society:}

Transgender community people often face denial and aggression right from home. Most families do not accept if their male child starts behaving in ways, which are feminine or inappropriate to the expected gender role. Consequently, family members may threaten, scold or even assault their son or sibling from behaving or dressing-up like a girl or woman and vice versa. Some parents may outright disown and evict their own child for crossing the prescribed gender norms of the society and for not fulfilling the roles expected from a male child. Parents provide several reasons, such as, bringing disgrace and shame to the family, no or less chances of their child getting married to a woman in the future, in particular, if they have only one male child, it will lead to the extinction of their generation and also inability on the part of their child to take care of the family in the future (Lev, 2004) (Chakrapani, 2012). Thus, transgender community men and women may find it difficult even to claim their share of the property or inherit what would be lawfully theirs. Sometimes, the child or teenager may decide to run away from the family not able to tolerate the discrimination or not wanting to bring shame to one's family. Some of them may eventually find their way to 'aravani communities'.

The troubles they face in family and society range from verbal and physical abuse, isolation, rejection and denial of family property. Sexuality or gender identity often makes transgender community a victim of stigmatization and exclusion by the society. Social stigma includes being disempowered due to the labeling and negative attitude towards such members who are forced to work as sex workers or sex solicitors. Even in cases of inheritance of property or adoption of a child, they are been neglected. Most members are forced to begging and some of them even engage themselves as sex workers just for their survival. In addition to the trauma of being abused, there are even no separate public toilet facilities for transgender community. A 2007 study documented that in the past years, the percentage of those transgender community reported for forced sex is 46 percent, physical abuse is 44 percent, verbal abuse is 56 percent, blackmail for money is 31 percent and threat to life is 24 percent (Padma,G. et al, 2008).

\section{B. Exclusion from Education:}

One of the serious flaws of our education system is that it does not facilitate skill acquisition especially at the secondary level. In India, as the children move to the higher classes the learning gap increases especially among weaker section/disadvantaged groups, which either results in higher drop out or creation of an unproductive workforce with little skill to sustain in the Job market. Such conspicuous gaps in the education system can be mended by giving skilled based education at secondary and higher secondary level especially to the transgender community.

Transgender community in the school face physical, sexual, emotional violence, violence in terms of neglect and discrimination as well. They often experience isolation and abuses, and are not been allowed to share common grounds with classmates (Shinu \& Nagaraj, 2015). Schools and colleges prove to be torment chambers for transgender community as they face accusations from teachers for violating educational and societal etiquette. This leads to zero acceptance level of transgender community in high school, higher secondary and college level.

Deprived by both education and family, transgender community students quit education or delimit the scope of education. The average qualification of a transgender community students is secondary or senior secondary 
level. The enrolment is significantly low and dropout rate at the primary and secondary level is still very high. Hence, they are pushed into forced illiteracy state (Bilodeau, 2005). Bridging the gap of gender disparity and social exclusion remains a huge challenge for the community as such.

Teachers accuse transgender community people because of ubiquitous societal norms and stigmas. This insensitiveness of teachers towards transgender community has an adverse impact on them. Most of teaching fraternity lack knowledge and sensitivity towards the issues of transgender community (Shinu \& Nagaraj, 2015). The transgender community person who is been already excluded from the family and society do not get enough support with the teachers and therefore forced to discontinue the education abruptly.

\section{Exclusion from Economic Rights:}

Most transgender community learners are school dropouts. Deficiency of adequate education leads to lack of employment opportunities, which eventually pushes transgender community into sex work and begging. While some transgender community people manage to sustain their jobs in spite of stigma and discrimination in workplace, most of them resign their jobs finding the situation unbearable (Chakrapani, 2012).

Most employers deny employment for even qualified and skilled transgender community people. Sporadic success stories of self-employed transgender community who run food shops, or organise cultural programs for their livelihood, are reported in some states, however, those are only exceptional cases). Lack of livelihood options is a key reason for a significant proportion of transgender community people to choose or continue to be in sex work - with its associated HIV and health-related risks (Chakrapani, 2010). Recently, there have been isolated initiatives that offer mainstream jobs to qualified transgender community people such as agents for Life Insurance Corporation (LIC) of India.

\section{Challenges faced by transgender community:}

Having understood the exclusion faced by the transgender community in social, cultural, educational and economic life, this section tries to draw attention to the challenges faced by transgender community.

\section{Challenges in family and society}

The mainstream society fails to understand that the culture, gender, and sexuality of transgender community and their social deprivation and harassment have never received attention by policy makers. Better understanding of socio-cultural and humanistic aspects of the discrimination against the transgender community would help in bringing about an attitudinal shift. Such an attempt at assimilation would require a review and reform of structural constraints, legal procedures and policies that impede access to mainstream education. Affirmative actions are needed to wipe out stigma and discrimination associated with the community and to improve the access to educational opportunities at all level. Schools and colleges need to play a supportive role in such instances, stepping in to ensure that education and/or vocational training is made available to these individuals.

\section{Challenges in welfare schemes and barriers to use existing schemes}

Social welfare departments provide a variety of social welfare schemes for socially and economically disadvantaged groups. However, so far, no specific schemes are available for transgender community as except some rare cases of providing land for transgender community in Tamil Nadu. Recently, the State Government of Andhra Pradesh has ordered the Minority Welfare Department to consider transgender community as a minority and develop welfare schemes for them. Stringent and cumbersome procedures need for address proof, identity proof, and income certificate all hinder even deserving people from making use of available schemes. In addition, most transgender community do not know much about social welfare schemes available for them. Only 
the Department of Social Welfare of Tamil Nadu has established 'Aravanigal / Transgender community Welfare Board' to address the social welfare issues of transgender community (Vidhya, 2008). No other state has taken up initiative so far to set up separate department as such. Transgender community mostly are not covered under any life or health insurance schemes because of lack of knowledge about the schemes available, inability to pay premiums, or not able to get enrolled in the schemes as such. Thus, most depend on the government hospitals in spite of the fact that they face insidious discrimination.

\section{Challenges in Civil, Legal and Political rights}

Legal issues can be complex for people who change sex, as well as for those who are gender-variant. Legal issues include legal recognition of their gender identity, same-sex marriage, child adoption, inheritance, wills and trusts, immigration status, employment discrimination, and access to public and private health benefits. Getting legal recognition of gender identity as a transgender community woman is a complicated process. Lack of legal recognition has important consequences in getting government ration card, passport, and bank account. Transgender community people now have the option to vote as a woman. However, the legal validity of the voter's identity card in relation to confirming one's gender identity is not clear (Padma \& Anirrudhan, 2008). Transgender community had contested elections in the past. It had been documented that the victory of a transgender community person who contested in an election was overturned since that person contested as a 'female', which was thus considered a fraud and illegal. Thus, the right to contest in elections is still a challenge to be addressed.

Legal provisions such as Indian Trust Act and Societies Registration Act enable a group of individuals to form a legal association pose challenges for transgender community. For instance, the need of address proof and identity proof of all members of the group is the basic requirement to register an association. However, most transgender community do not have identity and/or address proof or because they have documents only with their male identity. Similarly, opening a bank account to carry out financial transactions of their association proves to be difficult.

\section{Challenges in setting up and strengthening community based organizations}

Research studies reveal that only 103 organizations are working with transgender community people in India. Even among these, only half of these are community-based organizations. Transgender community has faced many challenges in community mobilization and legally registering their own organizations because generally government also supports more to the community-based organizations rather than transgender community having their own organizations.

\section{Challenges in public department offices and officials}

In spite of the above challenges, a few community-based organizations working for transgender community across India, were able to meet the legal requirements for registration. However, transgender community reportedly had issues with the government officials who are in-charge of processing the registration formalities they were asked unnecessary and irrelevant queries and there was unnecessary delay. Buying or hiring office space for the legal association is very difficult. Even if they get one, the landlords quote unfair rent prices.

A great majority of the transgender community ( 87.5 percent) stated that they have experienced problems caused by the police whether police officers from respective police stations (50.87 percent), railway police (26.31 percent), or traffic policemen (8.77 percent) (Anitha, 2015). Many expressed heart-rending experiences. It is important here to take note of the findings, which reveals that women being more favorable to transgender community than men. Of those who were harassed often, transgender community opined that they 
were beaten up by the police and warned not to beg (Anitha, 2015). There were also incidents which is narrated that definitely violates the basic human rights and the culprits go off, scot free because of the lacunae in the law.

\section{Challenges in funding support:}

Transgender community associations rarely get external financial support. Even those funders who might want to support primarily want to fund for HIV prevention activities (Norton et al, 2001). Through the National AIDS Control Programme, only a few Community Based Organisations (CBO) of transgender community have been granted projects.

\section{Challenges in the health care sector}

Transgender community face discrimination even in the healthcare settings. Often, healthcare providers rarely had the opportunity to understand the sexual diversities and they do not have adequate knowledge about the health issues of sexual minorities. Thus, transgender community face unique barriers when accessing public or private health services. Barriers in accessing HIV testing, antiretroviral treatment and sexual health services have been well documented. Types of discrimination reported by transgender community in the healthcare settings include: deliberate use of male pronouns in addressing transgender community registering them as males and admitting them in male wards, verbal harassment by the hospital staff and co patients and lack of healthcare providers who are sensitive to and trained on providing treatment/care to transgender community people and even denial of medical services (Chakrapani et al, 2004). Discrimination could be due to transgender community status, sex work status or HIV status or a combination of these

\section{Conclusion}

Problems and challenges of transgender community, which are to be addressed immediately and solved instantaneously include access to essential services, education, health and resources. These problems could be eliminated to some extent by implementing some progressive measures such as(i) sensitizing the society with regard to transgender community identity(ii) initiating efforts that support transgender community people to claim for land and shelter (iii) construction of separate public toilets, hospital wards (iv) recognition of their right to vote as citizens, reservation of seats in elections (v) support of media - both print and visual media, to highlight their status and plight rather than portraying them in the wrong sense, (vi) refraining from using verbal abuses against the transgender community and (vii) extension of financial support for community based organizations by transgender community. As all human beings, have the right to live with dignity, at all times, regardless of their legal, social or political status. Transgender community are also human beings and human rights and laws are applicable for them too. Conversation and interface between the transgender community and society through further research, mutual dialogue and coordinated efforts involving all sectors at the national and international levels could be the solution to embrace transgender community into mainstream society.

\section{References}

ANITHA, C., 2015. Problems Faced by Hijras (Male to Female Transgender) in Mumbai with Reference to Their Health and Harassment by the Police, International Journal Of Social Science And Humanity, Vol. 5, No. 9 .

BILODEAU, B., 2005. Gender, Power, and Social Justice: Transgender Students in Higher Education. Michigan. State University Press.

CHAKRAPANI, V., MHAPROLKAR, H., BASU, J., KAVI, A.R., 2007. Dynamics Of Men Who Have Sex With Men (MSM) And HijrasIn Maharashtra: A Qualitative Study On Sexual Networks And Vulnerability. Mumbai.The Humsafar Trust.

CHAKRAPANI, V., 2010. Hijras/Transgender Women In India: HIV, Human Rights And Social Exclusion,Issue Brief. New Delhi. UNDP. 
Also available at: URL>http://Www.Undp.Org.In/Sites/Default/Files/Reports_Publication/TG-Issue-Brief.Pdf

[Accessed on August, 29, 2017], 11.15 a.m.

CHAKRAPANI,V., 2012.The Case Of Tamil Nadu Transgender Welfare Board Insights For Developing Practical Models of Social Protection Programmes For Transgender People In India. New Delhi. UNDP.

CHAKRAPANI, V, BABU, P, EBENEZER, T., 2004. HijrasIn Sex Work Face Discrimination in the Indian Health-Care System. Research for Sex Work. New Delhi. UNDP.

CHAKRAPANI,V., SHUNMUGAM,M., MICHAEL,S., VELAYUDHAM,J., \& NEWMAN, PA., 2008. Barriers To HIV Antibody Testing Among People At Risk In Chennai, India. Indian Network for People Living With HIV. Asia Pacific Council of AIDS Service Organizations (APCASO).

Also available at:

URL>http://Www.Inpplus.Net/Images/DL_APCASO\%20Research\%20Report-Jun2008.Pdf

[Accessed on September 9, 2017], 10.05 a.m.

GOVINDAN, P., \& VASUDEVAN. A., 2009.The Razor's Edge OfOppositionality: Exploring The Politics Of Rights based Activism By Transgender Women In Tamil Nadu.

Also available at:

URL>http://Www.Lassnet.Org/2009/Readings/Govindanvasudevan2008razors- Edge.Pdf

[Accessed on September 14, 2017], 8.48 a.m.

LEV, A. I., 2004. Transgender Emergence:Therapeutic Guidelines For Working With Gender Variant People And Their Families. Binghamton, NY: Hawthorn Clinical Practice Press.

NORTON, A., CONWAY, T \& FOSTER, M., 2001. Social Protection Concepts And Approaches: Implications For Policy And Practice In International Development. London. Overseas Development Institute.

PADMA GOVINDAN \& ANIRUDDHAN VASUDEVAN., 2008. The Razor's Edge Of Oppositionality:Exploring The Politics Of Rights-Based Activism By Transgender Women In Tamil Nadu. Chennai.

ROBERT, K.,2009. Case Study Research: Design and Methods. Fourth Edition. California.Sage Publications.

SHINU ASMY \& NAGARAJ, P.,Preliminary Problems Faced in Educating the Third Gender Community. Asia Pacific Journal of Research. Vol: I. Issue XXVII, May 2015

ISSN: 2320-5504, E-ISSN-2347-4793

VIDHYA,V., 2008.Transgender Persons Are Finally Getting Their Due With The Tamil Nadu Government Announcing A Welfare Board For Them. New Delhi. Frontline.

Approach Paper To TheTwelfth Five-Year Plan Specifically Mentions About 'Lesbian, Gay, Bisexual, And Transgender community’ At Least Three Times In Relation To Health Policy And Social Equity.

Also Available at:

Http://Planningcommission.Nic.In/Plans/Planrel/12appdrft/Appraoch_12plan.Pd

[Accessed on September, 18, 2017], 4.16 p.m.

People's Union for Civil Liberties. 2001. Human Rights Violations against Sexuality Minorities In India. Karnataka.

Also available at:

Http://Www.Pucl.Org/Topics/Gender/2003/Sexualminorities.Pdf

[Accessed on September, 20, 2017], 12.14 p.m.

Tamil Nadu AIDS Solidarity Action Group (TASA), Tamil Nadu State Commission for Women and Actionaid. Tamil Nadu G.O. No. 38, Dated $15^{\text {th }}$ April 2008, Social Welfare - Aravani Welfare Board Formation Order.

United Nations. 2007. Theoretical Concepts Of Social Exclusion. Chapter 1. In: Literature Review On Social Exclusion. New York, NY: United Nations. 